\title{
Wystąpienie przez sąd krajowy z pytaniem prejudycjalnym do Trybunału Sprawiedliwości Unii Europejskiej a zawieszenie postępowania podatkowego
}

\section{Istota problemu}

Istota problemu sprowadza się do tego, czy wystąpienie przez sąd krajowy z pytaniem prejudycjalnym do Trybunału Sprawiedliwości Unii Europejskiej ${ }^{1}$, skierowanego w innej, indywidualnej sprawie, czyni zasadnym zawieszenie postępowania podatkowego na podstawie art. $201 \S 1$ pkt 2 Ordynacji podatkowej (dalej: o.p.).

Przy rozstrzyganiu tego problemu wskazać można i jednocześnie sformułować uzasadnione argumenty w odniesieniu do dwóch grup poglądów. Po pierwsze, nie ma dostatecznych podstaw prawnych do tego, aby uznać wynik sprawy z zakresu pytania prejudycjalnego do TS UE za zagadnienie wstępne, bezwzględnie warunkujące możliwość rozpoznania sprawy i wydania decyzji przez organ podatkowy. Po drugie, prounijna wykładnia art. $201 \S 1$ pkt 2 o.p. prowadzi do wniosku, że przepis ten może stanowić podstawę do zawieszenia postępowania podatkowego w przypadku, gdy wynik tego postępowania zależy od orzeczenia TS UE.

* Prof. zw. dr hab. Andrzej Gomułowicz - Katedra Prawa Finansowego, Wydział Prawa i Administracji, Uniwersytet im. Adama Mickiewicza w Poznaniu.

1 Na temat znaczenia orzecznictwa wstępnego Trybunału Sprawiedliwości Unii Europejskiej patrz: P. Dąbrowska, Skutki orzecznictwa wstępnego Europejskiego Trybunatu Sprawiedliwości, Warszawa 2004; M. Korniłowicz, Orzeczenia prejudycjalne Trybunału Sprawiedliwości Wspólnot Europejskich, [w:] M. Perkowski (red.), Wymiar sprawiedliwości Unii Europejskiej. Wybrane zagadnienia, Warszawa 2003; M. Szpunar, Procedura prejudycjalna z perspektywy unormowań kodeksu postępowania cywilnego oraz prawa o postepowaniu przed sąami administracyjnymi, [w:] C. Mik (red.), Pytania prejudycjalne w orzecznictwie ETS, Toruń 2006; Pytania prawne sądów państw członkowskich do Europejskiego Trybunału Sprawiedliwości (Sądu Pierwszej Instancji), [w:] A. Wróbel (red.), Stosowanie prawa Unii Europejskiej przez sądy, Kraków 2005. 


\section{Znaczenie i systematyka argumentów pierwszej grupy poglądów - sens i istota}

Argumenty, które skłaniają do uznania, iż brak jest wystarczających, tj. mocno uzasadnionych, podstaw prawnych do tego, by uznać wynik sprawy z zakresu pytania prejudycjalnego do TS UE za zagadnienie wstępne, które bezwzględnie warunkuje możliwość rozpoznania sprawy, a tym samym wydania decyzji przez organ podatkowy, w najogólniejszym zarysie można ująć w pewien usystematyzowany pod względem spójności sposób.

1) Zagadnienie wstępne wiąże się $z$ wystąpieniem przeszkody, która uniemożliwia rozstrzygnięcie sprawy podatkowej² . Zależności rozstrzygnięcia zagadnienia wstępnego i rozpatrzenia sprawy podatkowej nie można zatem utożsamiać z wymogiem ukierunkowania rozstrzygnięcia na określoną treść decyzji podatkowej. Od rozstrzygnięcia zagadnienia wstępnego powinno zależeć rozpatrzenie sprawy podatkowej w ogóle, nie zaś wydanie decyzji o określonej treści.

2) Od charakteru konkretnej sprawy, a niekiedy także stanowiska samego podatnika, powinno zależeć, czy orzeczenie TS UE będzie stanowiło zagadnienie mające te same cechy, co zagadnienie wstępne w rozumieniu art. $201 \S 1$ pkt 2 o.p., a więc zagadnienie mające wpływ na jej rozstrzygnięcie. Nie należy bowiem utożsamiać pojęcia zagadnienia (pytania) prejudycjalnego z art. $125 \S 1$ pkt 1 p.p.s.a. ${ }^{3}$ z zagadnieniem wstępnym art. $201 \S 1$ pkt 2 o.p.

3) W postępowaniu podatkowym, zasadniczą kwestię stanowi załatwienie sprawy konkretnego podmiotu w ściśle określonym terminie (art. $125 \mathrm{w}$ związku z art. 139 i n. o.p. $)^{4}$. Sprawność działania organów podatkowych ma znaczenie zarówno dla podmiotu występującego w stosunku do nich z określonym żądaniem, jak i dla państwa, z uwagi na możliwość sprawnej realizacji wpływów dochodów podatkowych do budżetu. W okresie zawieszenia postępowania podatkowego cel fiskalny nie jest realizowany. Tak więc, także z tego powodu zbyt szerokie odczytywanie znaczenia art. $201 \S 1$ pkt 2 o.p. nie byłoby uzasadnione.

4) Zawieszenie postępowania podatkowego z urzędu, mimo braku podstawy prawnej do uznania, że toczące się na tle podobnej sprawy postępowanie prejudycjalne przed TS UE stanowi zagadnienie wstępne w rozumieniu przepisów o.p., może prowadzić do stanu przewlekłości postępowania, a tym samym naruszenia prawa do dobrej i sprawnej administracji, a także uniemożliwić stronie w miarę

${ }^{2}$ Na sposób rozumienia pojęcia zagadnienia wstępnego patrz: wyrok WSA z dnia 8 kwietnia 2008 r., sygn. akt III SA/Wa 149/08; wyrok NSA z dnia 8 grudnia 2009 r., sygn. akt I FSK 1326/08; wyrok NSA z dnia 16 kwietnia 2010 r., sygn. akt I FSK 536/09.

${ }^{3}$ Ustawa z dnia 30 sierpnia 2002 r. Prawo o postępowaniu przed sądami administracyjnymi, Dz. U. z 2002 r. Nr 153, poz. 1270 ze zm.

${ }^{4}$ Patrz na ten temat: B. Gruszczyński, Zasada szybkości (art. 125 o.p.), s. 573-575 oraz R. Hauser, Termin załatwienia sprawy (art. 139 o.p.), s. 605-610, [w:] S. Babiarz, B. Dauter, B. Gruszczyński, R. Hauser, A. Kabat, M. Niezgódka-Medek, Ordynacja podatkowa. Komentarz, wyd. 5, Warszawa 2009. 
szybkie zainicjowanie postępowania sądowoadministracyjnego, mającego na celu kontrolę legalności wydanego przez organ rozstrzygnięcia. Tym bardziej, że sąd krajowy - w sytuacji gdy rozpatruje spór dotyczący stosowania przepisów krajowych, które mają na celu transpozycję dyrektywy do krajowego porządku prawnego - ma obowiązek interpretować prawo krajowe w taki sposób, aby w granicach swoich właściwości zapewnić pełną skuteczność i efektywność celom norm prawa unijnego, w tym celom traktatowym ${ }^{5}$.

5) Prawdopodobieństwo zarówno afirmatywnej, jak i negatywnej odpowiedzi na sformułowane przez sąd krajowy pytanie prejudycjalne, będące efektem powstałych wątpliwości przy rozpoznawaniu konkretnej, zindywidualizowanej sprawy podatkowej, co do zgodności czy też możliwości pogodzenia treści normy $\mathrm{z}$ przepisu krajowego z treścią normy wyprowadzonej z przepisu prawa unijnego, w sytuacji kolizji norm jest nie do przesądzenia do czasu wydania orzeczenia przez TS UE. Nawet bowiem w sytuacji, gdy w postępowaniu prejudycjalnym, zawisłym przed Trybunałem, Rzecznik Generalny przedstawi Trybunałowi swoją opinię, nie jest ona dla TS UE wiążąca i Trybunał może jej nie podzielićb.

6) Organ podatkowy powinien prowadzić postępowanie w taki sposób, aby decyzja była wydana z uwzględnieniem wykładni TS UE, ale wykładni już dokonanej, a nie wykładni przyszłej i co do wyniku niepewnej. Ustawodawca krajowy, właśnie w celu jak najszerszego czasowo uwzględniania przez organy podatkowe wykładni unijnej prawa podatkowego, jako jedną z przesłanek wznowieniowych w art. $240 \S 1$ pkt 11 o.p. wymienia orzeczenia TS UE.

7) Przewidziana w art. $240 \S 1$ pkt 11 o.p. przesłanka wznowieniowa stanowi wystarczająco efektywny środek proceduralny, który zapewni realizację uprawnień prawnopodatkowych wynikających z przepisów prawa unijnego.

\section{Znaczenie i systematyka argumentów drugiej grupy poglądów - sens i istota}

Rozstrzygnięcie problemu w zakresie dopuszczalności zawieszenia postępowania podatkowego, w przypadku pytania prejudycjalnego do TS UE, skierowanego w innej, indywidualnej sprawie, wymaga wskazania na następujące argumenty.

${ }^{5}$ Ten adresowany do sądów nakaz dokonywania wykładni zgodnej (interpretation conforme) wynika z systemu Traktatu o Funkcjonowaniu Unii Europejskiej i od lat ugruntowany jest w orzecznictwie ETS (zob. np. wyroki ETS: z dnia 10 kwietnia 1984 r. w sprawie C-14/83 von Colon i Kamann, Zb. Orz. 1984, s. 1891, pkt 26; z dnia 13 kwietnia 1990 r. w sprawie C-106/98 Marleasing, Zb. Orz. 1990, s. 4135, pkt 8; z dnia 05 października 2004 r. w sprawach połączonych C-397/01 do C-403/01 Pfeiffer i inni, Zb. Orz. 2004, s. I-8835, pkt 113, 114. Obowiązek sądu krajowego oznacza również, że w sytuacji, gdy sędzia krajowy ustali konflikt między normą prawa krajowego a prawa UE, nie ma obowiązku inicjować postępowania prejudycjalnego, ale może wydać rozstrzygnięcie w oparciu o zasadę pierwszeństwa na podstawie normy unijnej.

${ }^{6}$ Szerzej na ten temat patrz: D. Antonów, Wyktadnia prawa podatkowego po wstapieniu Polski do Unii Europejskiej, Warszawa 2009, s. 105-147. 
1) Rozstrzygnięcie problemu wiąże się przede wszystkim z wykładnią art. 201 $\S 1$ pkt 2 o.p., ale w tym otoczeniu prawnym, w którym ten artykuł obecnie funkcjonuje (związanie Polski dorobkiem prawnym UE, czyli: [a] unijnym prawem pierwotnym i prawem wtórnym, [b] zasadami ogólnymi prawa unijnego - pisane i niepisane reguły leżące u podstaw unijnego porządku prawnego) 7 .

W okresie przedakcesyjnym organy podatkowe, stosując prawo, zasadniczo dokonywały wykładni przepisów prawa krajowego, a czynności te były uwarunkowane jego charakterem. Ten charakter prawa krajowego wynikał z realiów polskiego systemu prawa, polskiej kultury prawa i przyjętych zasad interpretacji, które uwzględniały swoiste cechy prawa podatkowego. Właśnie owe cechy prawa podatkowego (ingerencyjny charakter) pozwalały na przyjęcie założenia o szczególnym znaczeniu elementów statycznych w procesie jego wykładni (a zatem preferowanie dyrektyw wykładni językowej) i marginalizacji elementów wykładni dynamicznej (znaczenie dyrektyw wykładni funkcjonalnej) ${ }^{8}$.

Przyjęcie dorobku prawnego Unii Europejskiej w znaczący sposób zmienia wymagania dotyczące podejścia do interpretacji prawa podatkowego. Zmiany te wynikają z charakteru źródeł prawa unijnego oraz relacji między prawem unijnym i prawem krajowym, takich jak przede wszystkim: zasada pierwszeństwa, zasada bezpośredniego obowiązywania, zasada bezpośredniego skutku9.

2) Ponieważ katalog źródeł prawa podatkowego, który obowiązuje w Polsce, uległ poszerzeniu o źródła prawa unijnego, to konieczne jest zapewnienie efektywności prawu unijnemu. Jest to jeden z podstawowych wyznaczników czynności interpretacyjnych, które powinny być podejmowane przez organy podatkowe dokonujące wykładni przepisów prawa. Przez pryzmat zasady efektywności prawa unijnego ocenia się zasadność wykorzystania wykładni językowej i pozajęzykowej, a także uznanie kolejności ich wyników ${ }^{10}$.

7 Patrz: R. Mastalski, Stosowanie prawa podatkowego, Warszawa 2008, s. 58-70; C. Kosikowski, Prawo Unii Europejskiej w systemie polskiego prawa finansowego, Białystok 2010, s. 187 i n.

8 W sposób kompleksowy na zagadnienia te wskazuje D. Antonów, op. cit., s. 54-64.

${ }^{9}$ S. Biernat, Zasada efektywności prawa wspólnotowego w orzecznictwie Europejskiego Trybunału Sprawiedliwości, [w:] idem (red.), Studia z prawa Unii Europejskiej, Kraków 2000 oraz idem, Prawo Unii Europejskiej a Konstytucja RP i prawo polskie - kilka refleksji, „Państwo i Prawo" 2004, z. 11; K. Czapracka, Zasada pierwszeństwa prawa wspólnotowego wobec prawa krajowego państw członkowskich a prace Konwentu przygotowujacego Konstytucję Europejska, [w:] C. Mik (red.), Unia Europejska w dobie reform, Torun 2004; K. Działocha, Podstawy prounijnej wyktadni Konstytucji RP, „Państwo i Prawo” 2004, z. 11; A. Kalisz, Wyktadnia i stosowanie prawa wspólnotowego, Warszawa 2007; A. Kalisz-Prakopik, L. Leszczyński, Zasady prawa w stosowaniu prawa wspólnotowego, „Europejski Przegląd Sądowy” 2005, nr 10; T. T. Koncewicz, Kilka uwag na temat interpretacji prawa wspólnotowego, „Palestra” 2004, nr 3-4; K. Kowalik-Bańczyk, Zasada efektywności prawa wspólnotowego, „Europejski Przegląd Sądowy” 2006, nr 4.

${ }^{10}$ M. Zieliński, Wyktadnia prawa. Zasady. Reguly. Wskazówki, Warszawa 2002 oraz idem, Derywacyjna koncepcja wyktadni jako koncepcja zintegrowana, „Ruch Prawniczy, Ekonomiczny i Socjologiczny" 2006, nr 3; S. Majkowska, Stosowanie i interpretacja prawa Unii Europejskiej, 
Trybunał Sprawiedliwości UE niejednokrotnie odwoływał się do wyników wykładni pozajęzykowych, i to pomimo że wykładnia językowa w pierwszym odbiorze prowadziła do oczywistych - jak by się mogło wydawać - wyników. W ocenie Trybunału odstępstwo nawet od jasnego sensu językowego jest możliwe wówczas, kiedy prowadzi do niesprawiedliwych następstw, a także gdy prowadzi do rezultatów, które nie dają się pogodzić z celami i zadaniami Unii Europejskiej ${ }^{11}$.

3) W zakresie procedury podatkowej obowiązuje ogólna zasada prawa unijnego, tj. zasada autonomii proceduralnej państw członkowskich. Zgodnie z tą zasadą organy stosują prawo unijne na podstawie swoich własnych przepisów proceduralnych. Przepisy te muszą jednak zapewnić jednostce możliwość dochodzenia roszczeń opartych na prawie unijnym przed organami krajowymi. Ponadto, przepisy te nie mogą kształtować mniej korzystnej pozycji jednostki w przypadku, gdy jej roszczenia są oparte na prawie unijnym, niż pozycja jednostki dochodzącej swych praw na podstawie prawa krajowego. Przepisy te nie mogą utrudniać ani tym bardziej uniemożliwiać dochodzenia roszczeń przez jednostkę. Wyznaczniki „niemożliwe” oraz „nadmiernie utrudnione” zostały określone jako celowościowe podejście do zasady autonomii proceduralnej ${ }^{12}$.

Procedura podatkowa pozostaje, co prawda, w gestii krajowych organów prawodawczych, jednakże prawo unijne wywiera pośrednio istotny wpływ także na zasady prawa procesowego, które stanowią podstawę funkcjonowania organów podatkowych. Zasada pierwszeństwa prawa unijnego odnosi się także do prawa procesowego. $Z$ uwagi na to, przepisy o.p. powinny być interpretowane $\mathrm{z}$ uwzględnieniem zasady efektywności prawa unijnego. Ich wykładnia musi czynić zadość normom prawa unijnego, gwarantując ich faktyczne funkcjonowanie w krajowym porządku prawnym.

4) Odwołując się do art. 120 o.p., a więc do zasady, że organy podatkowe działają na podstawie przepisów prawa i w ich granicach, należy dopowiedzieć, że obowiązek ten obejmuje obecnie również przepisy prawa unijnego. Praktycz-

[w:] A. Łazowski (red.), Unia Europejska. Prawo instytucjonalne i gospodarcze, Warszawa 2005 oraz S. Majkowska, Zasada stosowania prawa Unii Europejskiej na płaszczyźnie krajowej państw czlonkowskich, [w:] A. Łazowski (red.), op. cit.; A. Malec, Zasada pierwszeństwa prawa wspólnotowego przed prawem krajowym a wyktadnia prawa podatkowego, „Monitor Podatkowy” 2005, nr 2; patrz także: D. Antonów, op. cit., s. 65-91.

${ }^{11}$ Szerzej patrz na ten temat: A. Wróbel, Podstawowe problemy stosowania $i$ wykladni prawa wspólnot europejskich, cz. 1, „Casus” 2003, nr 30; cz. 2, „Casus” 2004, nr 32 oraz idem, Zasady ogólne (podstawowe) prawa Unii Europejskiej, [w:] A. Wróbel (red.), Stosowanie prawa Unii Europejskiej przez sądy, Kraków 2005; Podstawowe problemy przedstawiania przez Naczelny Są Administracyjny pytań prawnych Europejskiemu Trybunatowi Sprawiedliwości, „Zeszyty Naukowe Sądownictwa Administracyjnego" 2005, nr 1, zobacz także: K. Wójtowicz, Otwarcie Konstytucji RP na prawo międzynarodowe i procesy integracyjne, [w:] K. Działocha (red.), Podstawowe problemy stosowania Konstytucji RP, Warszawa 2004.

${ }^{12}$ Szerzej na ten temat patrz: D. Antonów, op. cit., s. 46-49. 
nie oznacza to, że aczkolwiek granice aktywności organów podatkowych są nadal wyznaczone przepisami prawa krajowego, to jednak obecne rozumienie zasady praworządności musi być wzbogacone o obowiązek działania również w ramach prawa unijnego. Z przepisem art. 120 o.p., podobnie jak z przepisem art. 7 Konstytucji RP („organy władzy publicznej działają na podstawie i w granicach prawa"), jednoznacznie koresponduje przepis art. 4 Europejskiego Kodeksu Dobrej Praktyki Administracyjnej. Przepis ten ujmuje zasadę praworządności w sposób następujący: „Urzędnik działa zgodnie z zasadą praworządności, stosuje uregulowania i procedury zapisane w przepisach prawnych Wspólnot. Urzędnik zwraca w szczególności uwagę na to, aby decyzje dotyczące praw lub interesów pojedynczych osób posiadały podstawę prawną, a ich treść była zgodna z obowiązującymi przepisami prawnymi" 13 .

W sytuacji, w której mamy do czynienia z wystąpieniem tzw. sprawy unijnej, aktualizuje się obowiązek organu podatkowego do specyficznej interpretacji tych przepisów, a zaniedbania w tym zakresie mogą, jako skutek, powodować powstanie obowiązku odszkodowawczego państwa wobec podatnika.

5) Zgodnie z art. 125 § 1 o.p. organy podatkowe powinny działać w sprawie wnikliwie i szybko, posługując się możliwie najprostszymi środkami prowadzącymi do jej załatwienia. Zawieszenie postępowania podatkowego w sytuacji wystąpienia przez sąd krajowy z pytaniem prejudycjalnym do TS UE służy realizacji zasady ogólnej postępowania podatkowego, wyrażonej w art. 125 § 1 o.p. Nie jest zatem zasadne wydawanie ostatecznej decyzji w sytuacji, gdy orzeczenie TS UE stanowić będzie przesłankę do wznowienia postępowania. Argument o wydłużeniu postępowania, z uwagi na jego zawieszenie, ma jedynie pozorny charakter. Zawieszenie zapewnia bowiem możliwość wydania w najkrótszym możliwym czasie prawidłowej decyzji, tj. decyzji uwzględniającej orzeczenie TS UE.

6) Zasada trwałości decyzji ostatecznych (art. 128 o.p.) służy pewności obrotu prawnego i jest istotną wartością krajowego porządku prawnego ${ }^{14}$. Wyeliminowanie z obrotu prawnego decyzji ostatecznych może nastąpić wyłącznie w szczególnych sytuacjach i stanowi to wyjątek od zasady trwałości decyzji ostatecznych. Nie należy zatem akceptować sytuacji, w której organ podatkowy dąży do rozstrzygnięcia sprawy - abstrahując od przyszłego i oczekiwanego orzeczenia TS UE - zakładając jednocześnie, że podatnicy będą korzystać powszechnie z trybu (wznowienia postępowania), który winien znajdować zastosowanie w jednostkowych i wyjątkowych przypadkach. Ponadto, z uwagi na termin złożenia wniosku o wznowienie postępowania, przewidziany w art. $241 \S 2$ pkt 2 o.p. (jeden miesiąc

13 Patrz: J. Świątkiewicz, Europejski Kodeks Dobrej Roboty (wprowadzenie, tekst i komentarz o zastosowaniu Kodeksu w warunkach polskich procedur administracyjnych), Biuro Rzecznika Praw Obywatelskich, Warszawa 2007.

14 Szerzej na ten temat patrz: B. Gruszczyński, Zasada trwałości decyzji, s. 580-581, [w:] S. Babiarz, B. Dauter, B. Gruszczyński, R. Hauser, A. Kabat, M. Niezgódka-Medek, op. cit. 
od daty publikacji orzeczenia TS UE w Dzienniku Urzędowym UE), możliwość jego dochowania przez podatnika staje się wysoce wątpliwa, a nawet wręcz iluzoryczna.

7) Brak zawieszenia postępowania podatkowego w sytuacji, gdy toczy się postępowanie przed TS UE, może spowodować znaczne wydłużenie postępowania podatkowego, a to wywołuje wątpliwości z punktu widzenia rzetelności procedury podatkowej oraz prawa do dobrej administracji. Wartości te znajdują źródło w Konstytucji $\mathrm{RP}^{15}$. Ochrona tych wartości nakazuje stosowanie przepisów proceduralnych w taki sposób, by minimalizować ryzyko generowania kolejnych, zbędnych procedur, których od początku można uniknąć. Ponadto, wątpliwe jest wydawanie decyzji, która z góry obarczona jest ryzykiem wadliwości i co do której istnieje wysokie prawdopodobieństwo, że i tak będzie musiała zostać wzruszona.

8) Jeżeli decyzja zostałaby wydana przed orzeczeniem TS UE, podatnik mógłby co najwyżej wnosić o wznowienie postępowania, ewentualnie o zwrot nadpłaty podatkowej. To prowadziłoby do wszczęcia kolejnego postępowania podatkowego w tej samej sprawie. Względy ekonomii proceduralnej, które wynikają z zasady rzetelnego postępowania administracyjnego oraz prawa do dobrej administracji, przemawiają za dokonaniem takiej interpretacji przepisów procedury podatkowej, aby uniknąć wskazanej wyżej sytuacji.

9) Decyzja podatkowa wydana przed orzeczeniem TS UE - jeżeli następnie okaże się, że wykładnia TS UE jest inna niż ta, którą przyjął organ podatkowy - może stać się źródłem uszczerbku (majątkowego i niemajątkowego) po stronie podatnika. Prowadzi do powstania roszczeń odszkodowawczych, a to nie jest korzystne z punktu widzenia interesu publicznego. Można tego uniknąć, jeżeli organ podatkowy zawieszałby postępowanie do czasu wydania orzeczenia TS UE. Ogranicza się bowiem ryzyko wydania decyzji niezgodnej z prawem unijnym.

10) Przepisy proceduralne mają zapewniać właściwe stosowanie przepisów prawa materialnego. Dlatego przepisy procedury podatkowej należy interpretować w taki sposób, aby zapewnić jak najdalej idącą ochronę podatnika przed ewentualnym naruszeniem jego uprawnień wynikających z prawa unijnego, a ponadto, aby zminimalizować ryzyko narażenia Skarbu Państwa na wypłatę odszkodowań wynikających z naruszenia prawa unijnego.

11) Jeżeli zagadnienie zgodności prawa polskiego z prawem unijnym jest przedmiotem rozpoznania w TS UE, to organ podatkowy powinien odnotować tę okoliczność i jeśli w ocenie organu podatkowego orzeczenie TS UE może mieć wpływ na treść decyzji, to organ podatkowy powinien prowadzić postępowanie podatkowe w taki sposób, aby decyzja była wydana z uwzględnieniem wykładni TS UE. Instrumentem proceduralnym, który organ podatkowy może wykorzystać w tym celu, jest zawieszenie postępowania podatkowego.

${ }^{15}$ Art. 2 Konstytucji, stanowiący o tym, że Rzeczpospolita Polska jest demokratycznym państwem prawnym, urzeczywistniającym zasady sprawiedliwości społecznej, a także treść preambuły do Konstytucji. 
12) Przedmiotem orzeczeń TS UE, mimo że formalnie przybiera ono postać wykładni prawa unijnego, jest najczęściej zagadnienie zgodności prawa krajowego z prawem unijnym ${ }^{16}$. Takie orzeczenie wywołuje liczne skutki prawne (obowiązek zwrotu nadpłaty, możliwość podnoszenia roszczeń odszkodowawczych). Trudno jest zatem uznać, że tego typu orzeczenie TS UE nie stanowi rozstrzygnięcia w rozumieniu przepisów proceduralnych o.p.

\section{Podsumowanie}

Problematyka zawieszenia postępowania podatkowego w przypadku pytania prejudycjalnego do TS UE, skierowanego w innej, indywidualnej sprawie, budzi kontrowersje i nie jest jednoznaczna. Na to wskazuje także orzecznictwo sądów administracyjnych.

W jednym z wyroków Naczelny Sąd Administracyjny wywiódł, że: „Rozstrzygnięcie przez ETS pytania prejudycjalnego NSA [...], nie stanowi zagadnienia wstępnego, o którym mowa w art. $201 \S 1$ pkt 2 o.p. Z zagadnieniem wstępnym mamy do czynienia w sytuacjach, w których wydanie orzeczenia merytorycznego, w sprawie będącej przedmiotem postępowania przed właściwym organem, uwarunkowane jest wcześniejszym rozstrzygnięciem określonej kwestii prawnej, ściśle związanej z tą sprawą (mającej wpływ na jej wynik), jednakże mogącej być przedmiotem rozpoznania jedynie przez inny organ lub sąd. Pomiędzy zagadnieniem wstępnym a rozstrzygnięciem sprawy musi istnieć związek przyczynowy; wystąpienie zagadnienia wstępnego powinno ujawnić się w toku postępowania, a jego rozstrzygnięcie należy do innego organu lub sądu. Bez uprzedniego rozstrzygnięcia zagadnienia wstępnego nie jest możliwe wydanie decyzji"17. W podobnym tonie utrzymany jest inny wyrok sądu administracyjnego, w którym sąd sformułował i uzasadnił następującą tezę: „Ustawodawca w przepisie art. 203 o.p. wskazał na prawa i obowiązki organu podatkowego i stron postępowania

16 Szerzej patrz na ten temat: P. Mikuli, P. Błachut, Uwagi o stosowaniu ustaw przez sądy w przypadku ich kolizji z prawem wspólnotowym, [w:] M. Kruk, J. Wawrzyniak (red.), Polska w Unii Europejskiej, Kraków 2005; J. Helios, Pojmowanie wykładni prawa europejskiego w orzecznictwie Trybunatu Sprawiedliwości, Wrocław 2002 oraz idem, Prawo europejskie jako rodzaj prawa, [w:] idem (red.), Autonomia prawa ze stanowiska teorii filozofii prawa, Wrocław 2003; K. Lasiński-Sulecki, Przyczynek do dyskusji nad gospodarcza wykładnia europejskiego wspólnotowego prawa podatkowego, [w:] L. Morawski (red.), Wykładnia prawa i inne problemy filozofii prawa, Toruń 2005; E. Łętowska, Multicentryczność współczesnego systemu prawa i jej konsekwencje, „Państwo i Prawo" 2005, z. 4; R. Mastalski, Wykładnia prawa podatkowego po wejściu Polski do Unii Europejskiej, „Przegląd Podatkowy” 2004, nr 8; M. Zirk-Sadowski, Wykładnia i rozumienie prawa w Polsce po akcesji do Unii Europejskiej, [w:] S. Wronkowska (red.), Polska kultura prawna a proces integracji europejskiej, Kraków 2005.

17 Wyrok NSA z dnia 8 grudnia 2009 r., sygn. akt I FSK 1326/08. 
podatkowego $\mathrm{w}$ sytuacji zawieszenia postępowania podatkowego z przyczyn określonych w art. $201 \S 1$ pkt 2 o.p., wśród których nie przewidział wystąpienia do ETS, jak również oczekiwania na ogłoszenie orzeczenia ETS. To dostatecznie dowodzi, że przewidywane ogłoszenie orzeczenia ETS nie stanowi zagadnienia wstępnego, od którego uzależnione jest, zgodnie z obowiązującym prawem, rozpatrzenie prowadzonej indywidualnej sprawy podatkowej zakończonej wydaniem decyzji”"18.

${ }^{18}$ Wyrok WSA z dnia 14 kwietnia 2011 r., sygn. akt III SA/Po 116/11. W uzasadnieniu sąd wskazał na przepis art. $240 \S 1$ pkt 11 o.p., według którego w sprawie zakończonej decyzją ostateczną wznawia się postępowanie, jeżeli orzeczenie ETS ma wpływ na treść wydanej decyzji. Ustawodawca przewiduje zatem możliwość ochrony interesów strony w sytuacji, gdy orzeczenie ETS będzie mogło wywołać wydanie innej decyzji niż ta, która została podjęta. 